This is an author produced version of a paper published in Annals of Public and Cooperative Economics.

This paper has been peer-reviewed but may not include the final publisher proof-corrections or pagination.

Citation for the published paper:

Nilsson, Jerker; Golovina, Svetlanda; Hess, Sebastian; Wolz, Axel. (2016)

Governance of Production Co-operatives in Russian Agriculture. Annals of

Public and Cooperative Economics. Volume: 87, Number: 4, pp 541.562.

http://dx.doi.org/10.1111/apce.12123.

Access to the published version may require journal subscription.

Published with permission from: Wiley.

Standard set statement from the publisher:

This is the peer reviewed version of the following article: Nilsson, Jerker; Golovina, Svetlanda; Hess, Sebastian; Wolz, Axel. (2016) Governance of Production Co-operatives in Russian Agriculture. Annals of Public and Cooperative Economics. Volume: 87, Number: 4, pp 541.562., which has been published in final form at http://dx.doi.org/10.1111/apce.12123. This article may be used for non-commercial purposes in accordance with Wiley Terms and Conditions for SelfArchiving.

Epsilon Open Archive http://epsilon.slu.se 


\section{GOVERNANCE OF PRODUCTION CO-OPERATIVES IN RUSSIAN AGRICULTURE}

Jerker NILSSON*

Department of Economics, Swedish University of Agricultural Sciences, P.O. Box 7013, SE-

75007 Uppsala, Sweden.Email: Jerker.Nilsson@slu.se.

Svetlana GOLOVINA

State Agricultural Academy, Ketovo district, Kurgan region, Russia 641300. E mail:

s_golovina@yahoo.com.

Sebastian HESS

${ }^{c}$ Department of Agricultural Economics, Christian-Albrechts-Universität zu Kiel, WilhelmSeelig-Platz 6, 24098 Kiel, Germany. Mail: shess@ae.uni-kiel.de. Phone: +49 431 880-1513. Fax: +49 431 880-4421. E- and Department of Economics, Swedish University of Agricultural Sciences, P.O. Box 7013, SE-750 07 Uppsala, Sweden.

Axel WOLZ

External Environment for Agriculture and Policy Analysis, Leibniz Institute of Agricultural Development in Transition Economies, (IAMO), Theodor-Lieser-Str. 2, 06120 Halle (Saale), Germany.E-mail:wolz@iamo.de.

ABSTRACT: Many Soviet kolkhozy and sovkhozy were transformed into agricultural production co-operatives, because the farm workers would have had large transaction costs in any other type of organisation. These co-operatives still hold a strong market position. This study explores the hypothesis that this market strength could be due to low governance costs, obtained through strong manager power. As managers want the co-operative to survive, they make limited investments in the co-operative and pay low wages. The members do, however, not consider this to be problematic. They appreciate the community within the village, their private plots of land and the co-operative's services. Hence the existence of the co-operatives is not threatened.

Keywords: Russia, production co-operative, labour co-operative, governance, agriculture

\section{Introduction}

In 1991, Russian law made it possible to establish agricultural firms compatible with the newly introduced market economy. The Soviet types of farms had to be restructured. "In place of collective farms, smaller, specialised farms using family and hired labour were expected to emerge as the backbone of Russian agriculture” (Wegren and O’Brien, 2002, p. 9). However, many of the Soviet collective and state farms (kolkhozy and sovkhozy, respectively) were fully or partly converted into agricultural production co-operatives.

In a market economy, agricultural production can be performed by various types of organisations such as production co-operatives, family farms and investor-owned firms. Under market conditions, the more efficient organisations will expand and the less efficient will decline (Schiller, 1969). Hence, the continuous existence of Russian production cooperatives may be an expression of these firms being efficient under certain conditions, provided that the country's agriculture is ruled by well-functioning market mechanisms that are not disturbed by political forces (Valentinov and Curtiss, 2005).

Agricultural production co-operatives, as defined by Russian legislation, conform to the general concept of co-operatives, i.e. organisations that operate in the interests of users, and

* Corresponding author. 
these users therefore control the organisation and own it (Dunn, 1988). The members are users, controllers and owners at the same time. Production co-operatives may be regarded as worker or labour co-operatives, as such co-operatives aim at offering good working conditions to their members.

It is a widely held opinion among economists that agricultural production co-operatives cannot compete successfully with family farms (Schmitt, 1991; Deininger, 1993; Binswanger et al., 1995; Allen and Lueck, 2005). It is argued that their collective nature gives rise to poor governance, for example capital constraints and misaligned incentives (Pollak, 1985). Family farming has an advantage as economies of scale are restricted because biological production is difficult to monitor (Johnson and Ruttan, 1994).

Nevertheless, production co-operatives are important in Russian agriculture and are also fairly strong (Golovina et al., 2013). According to federal public statistics, there were 11,850 co-operatives in Russia on 1 January 2014 (Rosstat, 2015), a rise from 7,939 in 1995 and 10,319 in 2012 (Maslova, 2013, p. 706). In 2009, co-operatives constituted about 32 per cent within the group of large agricultural enterprises and had a market share of 33 per cent (Golovina et al., 2012). The production co-operatives contribute an estimated 17 per cent of total Russian agricultural production (Wegren et al., 2008; O’Brien et al., 2011). Cooperatives operate in many regions of the Russian Federation and in several agricultural industries. Their market share may be up till almost 40 per cent (cattle farming) or lower (potatoes and vegetables, honey and fish production) (Petraneva et al., 2005).

An indicator of success is that the overall production value has increased even though the number of workers employed in the production co-operatives and the amount of fixed assets have fallen (Rosstat, 2010). The co-operatives survive in spite of a low rate of capital returns and poor utilisation of assets and labour (Minakov, 2007). All these trends may be seen as consequences of the members' wants for better individual returns.

This study examines the conditions for continuing existence of production co-operatives in Russian agriculture. While transaction cost theory may explain why the members prefer agricultural production co-operatives (Golovina et al., 2013), it does not explain why these firms are strong in certain regions and some agricultural production branches. Their collective structure could be expected to create high governance costs, so the co-operatives would be inefficient and unable to survive.

A number of studies have examined the importance of managers for the governance of the Russian production co-operatives (Amelina, 2000; Pugachov and Atta, 2000; Allina-Pisano, 2002; Lerman et al., 2004; Valentinov and Nedoborovsky, 2005; Petrick and Carter, 2009; Efendiev and Sorokin, 2013). However, there is a lack of theoretically based analysis of the governance structure of co-operatives, including the role of management. Therefore in the present study, governance theory analysis is used. The aim of the study is to explore whether the Russian agricultural production co-operatives have governance attributes that allow them to remain in business.

In the absence of reliable empirical data, this study seeks to synthesise findings from different strands of literature, mainly transaction cost and governance theory analyses of co-operatives in transition economies.

The paper is structured as follows: Section 2 presents the approach used in the study, followed by an account of the institutional framework under which agricultural production co-operatives have evolved. Section 4 clarifies the concept of governance, while Sections 5-8 explain how different types of governance costs appear in the Russian agricultural production co-operatives. Conclusions are drawn in Section 9. 


\section{Theoretical basis}

The focus in this study is on the institutional side of agricultural production co-operatives. Institutional theories explain structural patterns within industries, such as why production cooperatives exist in Russian agriculture, and are widely used by analysts dealing with cooperatives (Golovina and Nilsson, 2009; Hendrikse and Feng, 2013).

Similarly to other co-operative firms, the production co-operatives constitute partial vertical integration between economic actors. The members own the co-operatives. Hence the decision by agricultural workers to establish a co-operative and to remain as members can be understood with the help of transaction cost theory.

Golovina et al. (2013) used this theory in an analysis of data obtained from a survey of members of production co-operatives in the Kurgan Region of Russia. The study found that the workers of the large agricultural enterprises were in reality locked into large-scale farms and into their villages. All the determinants of transaction costs - asset specificity, uncertainties and transaction frequency - indicated that the workers would have great transaction costs were they to choose a form of organisation with a lower degree of vertical integration. The asset specificity was pronounced as concerns mental and social attributes. The workers resisted change and appreciated village life. Other limitations concerned the villagers' financial strength, infrastructure, time pressure, etc. The workers had in effect no alternative to production co-operatives.

... in many labor markets there is some degree of lock-in; after an individual has worked for a particular firm for a prolonged period, his or her skills are often specialized to that firm.

(Hansmann, 1988, p. 292)

While transaction cost theory explains why farm workers prefer agricultural production cooperatives, it does not explain why these firms have managed to survive for more than two decades. In order to analyse why the co-operatives have remained strong, there is a need for a governance theory toolbox, providing tools suitable for identifying some core attributes of the co-operatives. The governance theory framework includes agency theory and property rights theory.

Governance is often analysed with the help of agency theory. It is likely that there is a skewed power balance between managers and members of the Russian production cooperatives, not least because many co-operatives are successors to Soviet farms (Valentinov and Curtiss, 2005). The risk of shirking and free-riding is often high in collectively organised entities, but there is also a possibility for managers to dominate the members. The fact that the organisations are collectively owned and run implies that property rights theory is also a relevant theoretical area.

Macro-economic factors have a role to play, as they influence the determinants of the transaction costs, agency costs and property rights problems that appear in the agricultural production co-operatives. However, the present analysis does not focus explicitly on macroeconomic factors.

\section{Institutional conditions for agricultural production co-operatives}

\subsection{Production in Russian agriculture}

The first years after the Soviet break-up saw high inflation rates, political turmoil, late payments of public transfers, economic decline and rising unemployment, which led to one of the most severe recessions in economic history (Pugachov and Atta, 2000; Shutko, 2000; Tikhomirov, 2000). The agricultural sector was characterised by rising input prices, malfunctioning agricultural markets, an insecure legal environment and a lack of self-help organisations. By 1998, agricultural output had declined by 60 per cent due to the sharp costprice squeeze which occurred after price liberalisation in 1992, as well as reduced and 
ultimately abolished food producer and consumer subsidies and decreased domestic demand caused by falling income (Wandel, 2011).

In the years after the financial crisis of 1998, signs of an upturn could be observed. Depreciation of the Russian rouble by three-quarters provided an import substitution effect. Political reforms, a more stable macro-economic framework and increased profitability of domestic food production induced significant investment in the food industry and some investment in agricultural production. Economic recovery profited thanks to windfall gains from the rise in the export price of oil and gas (Rozelle and Swinnen, 2004; Anderson and Swinnen, 2010; Wandel, 2011). Although Russia later experienced a remarkable rebound in agricultural production, its production value only reached about 80 per cent of the 1990 level. While crop production had improved greatly, the animal production industry lagged behind (Wegren, 2011).

Supported by the Russian government, family farming multiplied rapidly after independence (Petrikov, 2000). Contrary to government intentions, in the early 1990s about two-thirds of farms were managed by people from a non-farming background. However, in the following years former rural dwellers formed the bulk of new family farmers (Wegren, 1998).

Government support waned from the mid-1990s due to the poor economic situation. The upstream and downstream sectors were privatised, but they mostly changed from government monopolies and monopsonies into private companies. Due to uncertainties and risks, the number of family farms declined and, according to the official federal statistics office, was 47,316 on 1 January 2014 (Rosstat, 2015).

The importance of food production on household plots increased after the collapse of the Soviet Union. In 2002, more than 30 million household and garden plots were registered, comprising about 28 million hectares (Uzun, 2008). The contribution of these household plots to food production then declined, however, from 56 per cent of total agricultural production in 2002 to 40 per cent in 2008. During the same period, the large farms increased their share of food production from 40 to 49 per cent, while family farms increased their share from four to nine per cent (O’Brien et al., 2011).

The emergence of these various organisation forms is claimed to be partly the result of government action (Amelina, 2000; Pugachov and Atta, 2000; Lerman and Schreinemachers, 2005; Visser and Spoor, 2011). For example, government offices in some regions stimulated the creation of family farms, while others supported large agricultural enterprises (Epshtein et al., 2013).

\subsection{The establishment of production co-operatives}

The establishment of agricultural production co-operatives was advocated by most regional agricultural administrations (Golovina et al., 2012). Either a whole Soviet farm could be transformed into a production co-operative or the workers could take out their individual share of the total equity and eventually form a new co-operative. The co-operatives based on complete transformation initially had advantages in that they already had production means, could continue with the existing production orientation and had minor problems with staffing, supplies of resources and marketing of products.

In connection with the complete transformation of former Soviet farms, the workers first had to inform the enterprise's privatisation commission that they wished to use their property share as an entrance fee. The privatisation commission was then intended to allocate a corresponding part of land and assets, but there was no clear pattern to follow.

If the workers wanted to establish a new (usually small-scale) co-operative from scratch, in general they received support from their former collective entities. After approval by the general assembly, the land could be transferred to those members as either jointly used and owned, or jointly used and individually owned, property. The area of land allocated to each 
member in the former enterprise was calculated by dividing the total land area by the number of workers, including other employees and pensioners. A newly-established co-operative could obtain a greater acreage by renting land, with the option of buying it later.

Russian legislation demands that production co-operatives be voluntary associations of citizens who become members in order to conduct joint production or other economic activity based on their personal labour, as well as their investments in shares. When a Soviet farm was transformed into a production co-operative, the formal decision was made by the workers.

The legislation admits members of varying legal status within three categories: people who work in the co-operative; people who do not work in the co-operative but may be involved in other types of related activities; and legal entities, which operate in the co-operative through representatives. If members of the second and third categories are included, their combined number must not exceed one-quarter of the total membership. All members have one vote, irrespective of the shares they own and their official position.

A co-operative society's assets comprise the share capital paid by members, accumulated profits from co-operative activities, credits and other sources. The equity capital consists of members' shares, but there may also be unallocated capital (indivisible funds). The existence of the indivisible funds differentiates co-operatives from other business organisations. They provide the co-operative with a more stable financial status. Part of the indivisible funds may be transferred to the reserve fund intended to cover losses. The net profits that a co-operative makes, if any, are meant to be distributed between working and non-working members.

Any new member has to buy a share of the co-operative. The amount may be paid in different ways, such as in cash, securities or other assets (e.g. buildings, premises, equipment and vehicles), rights of use of buildings or the results of intellectual activities. Land and other natural resources may also constitute a share. The fact that the share capital can be paid with assets and not in cash is a consequence of how the assets of the former Soviet farms were distributed among the working members at the time of transformation.

Formally, the members own their shares but their ownership rights are demarcated. The decision making power over the co-operative's entire assets lies in the hands of the cooperative's leadership. The co-operative can cultivate land, which can be brought in by members in the form of share funds, transferred to it for rent, or redeemed by the co-operative society.

Withdrawing members receive their invested share of capital from the co-operative in monetary terms, although at current value, provided that the co-operative has sufficient liquidity. Alternatively, the withdrawing member may receive land or other assets.

\section{Governance}

Governance refers to monitoring and incentivising, both of which demand resources from the owners of the organisation. The owners must monitor the firm's performance and they must design incentive schemes to motivate managers, workers and other stakeholders to attain good performance. Irrespective of business form, the owner of a firm has to use efforts, money and other resources to govern their firm. There are governance costs.

Hence, members of a co-operative make sacrifices when governing their firm. The members (including the directors and the manager) have to collect and process information about the co-operative and its existing and prospective stakeholders in order to make management and investment decisions. Hansmann (1996) mentions four major types of governance costs, which

... include (i) the costs of making collective decisions among the owners, (ii) the costs of monitoring managers, and (iii) the costs of the poor decision and excessive managerial discretion 
... Another cost is (iv) the risk bearing associated with receipt of residual earnings. (Hansmann,

1996, p. 21; numbering added here)

The firm owner's governance costs must be weighed against the returns that the firm provides to the owner. The higher the governance costs the owner has, the higher the returns must be if the owner is to continue being interested in owning the firm. Rising governance costs mean that the owner will lose control of the firm as the efforts become less profitable. If the owner does not find ownership worthwhile, he or she could sell the firm to somebody who may have either lower governance costs or higher profit potential, or both.

If the organisation is a co-operative, the members must consider their governance costs to be lower than the benefits that they obtain in terms of transaction cost savings (Ginder and Delter, 1989; Iliopoulos and Hendrikse, 2009). So the members' transaction costs and their governance costs are interrelated. When members think that there is a need for high governance costs, they will care less about managing the co-operative. If the governance costs rise sufficiently, they may want to leave the co-operative.

The four types of governance costs identified by Hansmann (1996) are discussed below in the context of the Russian agricultural production co-operatives. The task is to explore whether the existence of the production co-operatives can be explained by the members having governance costs that are lower than the benefits they get from belonging to the co-operative.

\section{Costs of making collective decisions}

\subsection{Establishment of co-operatives}

When an organisation is to be established, somebody has to make a large number of investment decisions, for example concerning statutes, financial solutions, recruitment of staff, production facilities, etc. The founder of the organisation will thus face so-called organisational costs when investing work, money and other resources. However, after the firm has been established, the founder will be the owner of a firm, the value of which should exceed the invested resources. The founder thus has an incentive to make the investments necessary for the organisation to be started.

The organisational costs are problematic when it comes to the establishment of collective organisations such as co-operatives. The absence of individual property rights in such an organisation means that those who benefit from the organisation's services have no incentive to contribute to the establishment of the organisation. If such an organisation is to be established somebody has to take action, thereby carrying the organisational costs alone. Others, being free-riders, will enjoy the benefits from this collectively owned organisation without carrying the organisational costs (Olson, 1965).

If this reasoning were to be generally correct, no co-operatives or other collective action organisations would exist. As such organisations actually exist in probably all economies, Olson (1965) proposes some ways to overcome the misalignment between individual and collective property rights. His arguments are divided into three categories, namely "group size”, "by-product” and “coercion”. A fourth category, “altruism”, is added below.

One possibility is that collective action organisations are established by a small group of individuals - the "group size" argument (Olson, 1965). Provided that the group is small enough, the organisational costs may be minimal. After the organisation has been established other individuals may be enrolled. The founding members may benefit from letting the group expand to reap economies of scale and scope. It may be assumed that if the small number of founding members remains in control, they have a strong incentive to work for the organisation's well-being.

Furubotn (1976) notes that establishing a co-operative becomes more costly if there are negotiations within a large group of potential members compared with a situation where a 
group already exists. Furthermore, the costs of expanding the membership of a co-operative become lower if new members can be recruited one after another, because then the new members will have to accept or reject an existing set of conditions. These conditions were decided upon when the co-operative was founded and the founding members are, reasonably, not willing to negotiate the terms (Furubotn, 1976).

Observations from the history of co-operatives in the Western world confirm this view. Cooperatives have been established at village level, often at the initiative of the larger and richer community fellows, and have then expanded successively into neighbouring villages. To reach the large size of today's agricultural and consumer co-operatives, a large number of mergers have taken place. Those mergers corroborate the argument that the organisational costs are low when two firms negotiate with one another to create a larger unit.

Olson (1965) also mentions a "coercion” argument for the establishment of a collective action organisation. Under certain circumstances, some actors have possibilities to force others to become involved in a collective action organisation. They may use legal force, although probably more often economic or social force.

Third, there is the "by-product" argument for establishment of a collective action organisation (Olson, 1965). An existing organisation - one that does not produce collective goods - may take up production of collective goods. The principals in the former organisation may gain advantages from reorienting the organisation.

The reasoning above can be applied to the Russian agricultural production co-operatives, which are a specific type of collective action organisation. The vast majority of these cooperatives were established when the Soviet farms had to be converted into other organisational models, and so the organisational costs were relatively small. The former Soviet farms could easily be restructured into production co-operatives with most of the workers turned into members and most of the assets handed over to the new entity. Only a few production co-operatives have been established from scratch.

When the Soviet agricultural enterprises were transformed into agricultural co-operatives, the management played a core role in the establishment process. The small group of managers were catalysts for these collective organisations, i.e. the "group size" argument applies. The managers had a personal interest in the formation of co-operatives. Hence, they made large efforts to convince the workers to choose a co-operative solution.

It is possible to think of situations where managers of socialist enterprises promoted the choice of organizational forms supporting large-scale production-specifically, producer cooperatives - with the intention of maximizing their own welfare by retaining managerial positions in the newly established enterprise. (Valentinov and Curtiss, 2005, p. 40)

Similar reasoning applies for a collective action organisation after it has been established and is a going concern. Members at large may receive the benefits of the organisation's activities without paying accordingly. Hence there must be a small group or even an individual manager who runs the organisation. Without strong management, it is not likely that the production co-operatives would survive and be relatively strong. The managers do this because they can reap personal benefits of various kinds - monetary, reputation, social recognition, etc.

The "coercion" argument behind the formation of the Russian co-operatives is applicable to the extent that the workers of the Soviet farms had no alternative employment. They were subject to economic coercion. However, there was also social coercion, as the workers did not want to give up the social ties that they had to each other. The social relationships that the villagers had to one another seem to have been important to their decision. The production co-operatives' "workers have preferences for behaving in conformity with their social reference group” (Petrick and Carter, 2009, p. 231). 
A specific kind of coercion stemmed from the fact that the transformation into a production co-operative was based on a single majority decision among the workers of the Soviet farms. So the majority forced the minority into the co-operative. This is one of the reasons why so many co-operatives were formed. The number of new co-operatives was larger than if a qualified majority vote had been required. Those who were against the transformation were obliged to comply with the majority decision, unless they opted to leave the co-operative. Thus the membership of production co-operatives exceeds the number of workers who voted in favour of these co-operatives.

The "by-product" argument could possibly be applied, as the former Soviet agricultural enterprises were in reality government structures integrated in the central planning system for feeding the nation's population. As the Soviet Union fell apart, these firms changed their purpose to become vehicles for the managers and workers of the farms.

There is still another possible explanation for the existence of collective action organisation, namely "altruism". However, this not mentioned by Olson (1965), whose point of departure was that of the economist's "economic man”, i.e., self-interest seeking. This assumption has been criticised by some other researchers (Hardin, 1982; Hansmann, 1996), who suggest that collective action organisations may be established by benevolent individuals in attempts to help people in need. People may also establish collective organisations due to a passion for a cause or activity, for example sports, culture, leisure or hobbies.

It is difficult to find indicators that the establishment of the Russian agricultural production co-operatives was a consequence of care for others. The possibility that the leaders of the Soviet farms had some social concerns when they advocated the formation of production cooperatives cannot be fully excluded. However, this is countered by Golovina et al. (2013; 2014), who show that there is a discernible amount of group-level social capital within parts of the co-operative memberships, while the amount of individual-level social capital in the relationship between the members and the managers is very limited (Valentinov, 2004). The members do not have much trust in the management.

\subsection{Strategic reorientation}

Problems may arise if a membership is to unite upon a decision about a strategic reorientation of an existing and running co-operative. If such a decision is made in a member democratic fashion, the organisational costs are likely to be large, especially if the degree of heterogeneity within the membership is high. This situation is similar to that of establishing a new co-operative, because there is a need for much time, effort and money, and each member has a weak incentive to take the reorganisation burden. The individual members want to be free riders, hoping that somebody else will invest.

The manager of an existing co-operative has, however, incentives to lead the reorientation process. The manager may realise that the co-operative has poor survival chances unless it is restructured. Moreover, the manager may want to continue as a leading figure for egoistical reasons. An exception to this is that the co-operative may be in such bad shape that no reorganisation would help or the manager may be close to retirement or moving to a new post in another firm.

There is no empirical evidence per se about Russian agricultural production co-operatives being reorganised but a satisfactory process must have been conducted, since otherwise the co-operatives could not have survived for more than two decades. Hence it is reasonable to assume that the co-operatives have powerful and strongly motivated managers.

[A] factor that must not be ignored is the traditional power of the manager, both as an omniscient community leader who decided everything in the village and as a representative of the outside authorities (regional or federal). In many instances, the manager exercises influence to prevent 
deep restructuring and preserve the large-scale organization as a way to keep his power and his perquisites. (Lerman et al., 2004, p. 149)

As the discussion above indicates, the establishment and the further development of the Russian agricultural production co-operatives are dependent on the motivational factors that a powerful manager may have. The members at large have less to say, i.e. the power balance is to the advantage of the manager. Members were influenced by the managers when they decided to establish co-operatives and such influence is still strong (Allina-Pisano, 2002; Petrick and Carter, 2009).

Some factors indicate that much power is in the hands of the managers of the Russian cooperatives. One such factor is the mentality within the membership and the traditions that were formed during the Soviet era. “... Russian rural territory tends to demonstrate strong communality, little spread of entrepreneurial activity and a preference for working in vertically integrated enterprises...” (Efendiev and Sorokin, 2013, p. 111). The decisionmaking structure is likely to have been inherited from the Soviet farms (Golovina et al., 2014).

Another factor is that centralised power will reduce tensions between the interests of the collective and those of individual members, seeking personal advantages on behalf of the collective. Such conflicts may be expected to be widespread because a production cooperative is not only responsible for work, but also for various other tasks in the community.

As concerns the tension between individual and collective interests, had members been given the right to decide about how to allocate the co-operative's money, the individual members would probably have preferred investments that would have given them individual property rights to various assets. Long-term investments to the benefit of the entire membership have to be made by the leadership. According to Golovina et al. (2014), many members of the Russian production co-operatives accept such personal sacrifices.

Provided that the managers want to keep their powerful position they care about the survival of the co-operative. Therefore they do not pay the members high wages, patronage refunds or dividends. Furubotn (1976) indicates that managers will act as though the co-operative were their privately owned firm.

... the volume of self-financed investments planned in any period depends on the contemporaneous volume of consumption by the original membership of the collective and this volume of consumption is in turn decided by the initial majority. (Furubotn, 1976, p. 111)

The managers of today's production co-operative are likely to have more power than the managers had in the Soviet farms. The co-operatives are not dependent on higher state authorities while the Soviet farms belonged to a governmental hierarchy.

In roughly two-thirds of the enterprises surveyed, reorganization of the agricultural enterprise to a different legal form did not lead to a change in the management. ... Furthermore, no significant changes in the management methods of the newly created farm businesses were noted. (Pugachov and Atta, 2000, p. 535)

An indicator of strong managerial power may be that the average membership of the Russian production co-operatives is declining and the standard of living is comparatively low (Golovina et al., 2013). This development would be less likely if the members were to decide by themselves, but it may be the result of powerful managers trying to improve the financial status of their co-operative. Provided that production volumes are stable, a lower number of workers means increasing production per person. The members may share the fruits of their work with fewer others, so the average member becomes better off. Thus dilution of the resources is avoided.

A conclusion from the account above is that the establishment and continued development of the production co-operatives is most likely the outcome of efforts by a small group of strong 
managers. The managers of the Soviet farms, many of whom later became the managers of the co-operatives, are core figures in this development.

\section{Costs of monitoring management}

As an organisation expands and reaches a certain size and complexity, the owner will no longer be capable of governing it alone. Hence, the need to employ a professional manager arises. The manager will normally have or acquire better knowledge of the firm than the owner. Information asymmetry will thus arise, whereby the manager gets power over the owner (Jensen and Meckling, 1976; Barney and Ouchi, 1986). The owner thus gets agency problems, which result in agency costs.

Due to the information asymmetry the principals are not able to prevent the agents from being fraudulent. The principals can protect their interests to a certain extent, however. Because such measures are resource-demanding, the principals will face a cut-off between the preventive costs and the losses. One class of agency costs concerns the principals' monitoring of the agents. The principals must use resources to regulate and monitor the behaviour of the agents. This is done partly by establishing a contract and partly by controlling and ensuring fulfilment of that contract (Nilsson, 2001, 334).

The same reasoning applies irrespective of the organisation form, i.e. co-operatives must also have professional managers. The members would have extremely high organisational costs if they were to negotiate, collect and process information etc. relating to the co-operative's investment decisions on their own. These costs are effectively reduced by delegating the tasks to managers. Thus the members (principals) hand over power to managers (agents).

Agency problems are widely discussed in the literature on co-operative organisations. This is because of the collective nature of co-operatives, i.e. the principals are a large number of individuals, each with their own - often conflicting - interests. There is no possibility for power concentration in co-operative membership, as is often the case in investor-driven firms (Nilsson, 2001).

Examples of monitoring measures irrespective of business form are independent auditing, policy documents, annual reports and general assemblies. Owners of investor-owned firms often implement interest-aligning salary schemes and options for the managers to buy shares, but these measures do not function in co-operatives, where the residual earnings depend on the amount of payment to the members. The market for equity capital has the function of disciplining managers of investor-owned firms, but the equity capital in co-operatives is not subject to any market forces.

A number of studies have indicated that the Russian agricultural production co-operatives are characterised by large agency problems, i.e. that the members cannot prevent the managers from acting in their own interests (Amelina, 2000; Allina-Pisano, 2002; Lerman et al., 2004; Valentinov and Nedoborovsky, 2007).

[Managers] may also withhold information concerning privatisation and other civil rights, prevent political organisation of farm workers, exclude outsiders ("change agents") from the village, inhibit the creation of support networks or business for private farmers, frighten defectors and local "collective" solutions to problems. (Petrick and Carter, 2009, p. 237)

When comparing the Russian agricultural production co-operatives with co-operatives in Western economies, there is a striking difference in terms of collectivism, which may be explained by the history of the Russian co-operative movement (Golovina et al., 2012). In Russia the assets are collectively owned and the work is conducted jointly. Such collectivism is likely to create a barrier between the members and the leadership. The members' lack of trust in the managers indicates the existence of free riding and other agency problems (Hagedorn, 2014). 
[T] here is social capital in the membership group, although the amount is not overwhelming and it is unevenly distributed. Members who consider co-operatives to be an efficient business form have social ties to other members, while the leadership does not enjoy much social capital within the co-operative. The members regard the co-operative basically as a social unit, not as a business enterprise. (Golovina et al., 2014, p. 535)

The existence of non-working members in the Russian co-operatives may reduce the amount of agency problems. The co-operative thereby obtains a stronger position in the local community and external parties have an interest in the co-operative's success. As the investing members demand capital returns, the managers' possibility of abusing power becomes restricted. The broadening of membership is also a means to counter underinvestment (Bonin et al., 1993).

\section{Costs of poor decisions and excessive managerial discretion}

\subsection{Residual losses and bonding expenditure from a member perspective}

Even though the principal tries to monitor the agent, the latter has freedom of action and can thus extract rents from the organisation to the disadvantage of the principal. Hence, a second category of agency costs is residual losses: "[I]t is the agent who is able to direct the organisation so that its surplus may be smaller and so that he personally may usurp some of the surplus” (Nilsson, 2001, p. 334).

A third category of agency costs is bonding expenditures on the part of the agent. "In order to reassure the principal that he is acting in accordance with the interests of the principal, the agent must employ a certain amount of resources” (Nilsson, 2001, p. 334).

The agent's usurpation of part of the residual earnings and use of bonding expenditures hurt the interests of the principal, but the principal has difficulties in preventing such fraud. The agent will try to conceal this behaviour, and the principal may consider it to be unavoidable. The extent to which this may happen in the production co-operatives depends on how the member democracy system functions.

Problems concerning the governance of co-operatives are often described in the literature. A classical sociological theory, “The Iron Law of Oligarchy” (Michels, 2001 [1911]), states that it is impossible to retain member influence and member involvement in a large organisation working for the betterment of a large group of persons. There is a need for coordination and thus for leadership. A powerful clique will evolve and gain control of the organisation. These power holders have an incentive to preserve their power in order to reap personal advantages. Thus they have an interest in the organisation's survival, regardless of the interests of the members, while the members' interests are met only to the extent that the members remain in the organisation. The members at large have neither any possibility nor any incentive to involve themselves in the leadership, not even to get correct information about the leadership. Oligarchical leadership is thus unavoidable in collective organisations.

Managers' expropriation of rents from co-operatives is thus described by Furubotn (1976, p. 121): "the labor-managed firm is controlled by particular individuals having the power to shape the firm's investment, employment, and output policies to suit their own specialised objectives" (see also Furubotn and Pejovich, 1970). Hence, the managers conduct measures which are not in perfect accordance with the members' wishes. This results in the managers' planning horizon becoming limited to their "period of tenure" (Furubotn, 1976, p. 122). The observations made within the Russian agricultural production co-operatives are much in line with these statements.

\subsection{Members' control of managers}

As in co-operatives in general, the Russian agricultural production co-operatives have formally democratic governance. However, it appears that the co-operative managers have a 
decisive role. The achievements of the co-operative firms are contingent upon the leadership. This is not to say that the leaders necessarily try to enrich themselves. They may also use their power position in the interests of the membership (Golovina et al., 2014). Hence there is room for some speculation.

The eventual 'democratic deficit' may perhaps be counterweighed by social forces. The manager lives and works amongst the members and knows everybody, and all members know the manager. These social relationships may exert control on the manager, in which case there may be opportunities for functional democratic control and good business operations. Prior to major investment decisions, the manager may consult the membership and explain the decisions. Another circumstance that points in the same direction is that the managers have to show good enough business results; otherwise the co-operative's survival may be threatened.

Alternatively, the manager reaps advantages as the conditions for agency problems exist. The manager is more knowledgeable and has the power to make many decisions autonomously. The manager is held responsible by the membership only when the yearly general assembly is held. The contracts between the co-operative and the manager are of necessity incomplete, which gives rise to a skewed relationship (Pencavel, 2001). Historical influences, from Soviet times, may underpin such a situation.

The managers' desire to remain in power is focused on when Furubotn (1976) explains why labour co-operatives are reluctant to expand their membership and reach the economically optimal size. Expansion is resisted by the leadership, who has succeeded in establishing a common concept of how the co-operative should be run, organised and financed. When new members are included, the existing power balance is threatened. New members mean increasing heterogeneity and increasing risks and difficulties. As Furubotn (1976, p. 107) states, “... the members of the original majority will be relatively cautious and suspicious of changes. Any enlargement of the collective tends to make their political control less secure and promises some deterioration of the firm's environment”. The negative effect of an expanding membership may exceed the advantages of lower average production costs through large-scale operations.

The reluctance of labour co-operatives to expand is, according to Meade (1972, p. 416), due to the fact that the co-operative's “objective is to maximise a residual surplus per unit of a factor input, i.e. earnings per worker”. By keeping the membership small, each individual will own a larger share of the co-operative's collective capital, and the income per individual will increase (Pencavel, 2001).

The Russian production co-operatives are on average smaller than their investor-owned competitors. This may be positive, as the governance costs may be lower, i.e. the agency problems may be more manageable. Meade (1972), based on Vanek (1970), demonstrates that worker co-operatives have advantages given that the scale of operation is relatively small, because "a reduction of workers increases the direct economic incentives for efficiency of the individual worker" (Meade, 1972, p. 404). Thanks to social control the free-rider problem is less serious in co-operatives with small memberships and much less than in their investor-owned competitors, where the workers do not have any ownership.

\section{Costs of risk bearing associated with receipt of residual earnings}

The principal of an organisation is entitled to receive the residual earnings that result from the operations of this organisation. This is formally the case in the Russian agricultural production co-operatives too, but in reality it is uncertain to what extent the members receive the residual earnings. If only a limited share of the residual earnings is distributed, the members face an extra agency cost. 
Golovina et al. (2013) claim that members have problems in obtaining their proper share of the Russian agricultural production co-operatives' profits. These difficulties are related to the fact that the co-operatives are not only production units, but also run multi-purpose operations. Likewise, the members have multiple objectives, not only of a monetary nature but also in terms of various social benefits. The possibility cannot be excluded that the members appreciate these social benefits more than eventual monetary benefits.

It is important to recognize, however, that the income streams have both pecuniary and nonpecuniary components; thus, something beyond simple monetary accounting is needed. The nature of the choice set can be clarified by considering some specific examples of the rewards that are available. (Furubotn, 1976, p. 108)

Golovina et al. (2013) found that members of Russian production co-operatives are not primarily interested in their material standard. They want to have a quiet and stable life. There are indicators of risk aversion within the membership. The social community within the villages is appreciated by the members. Furthermore, the workers may not get high wages from the co-operative, but they get different kinds of social support. An important factor is that members cultivate their privately owned plots of land, which surround their homes, or they have livestock and poultry. A large share of the villagers' livelihood originates from these sources.

These findings indicate that respondents focus on their private lives, are far from business-minded, and avoid uncertainties. ... [T] hey prefer to stay with what is well-known and safe, i.e. membership of the production co-operative together with friends and relatives in their home village. (Golovina et al., 2013, p. 484)

While co-operative members may appreciate social factors just as much as economic factors (or even more), economists tend to regard such structures as creating inefficiencies. For example, Meade (1972) considers the low standard of living among members of labour cooperatives to be problematic. The members do not have the possibility of deploying their labour in a different organisation, which means that they bear a greater risk. They 'put all their eggs in one basket', i.e. there is much asset specificity. In contrast, capitalists tend to invest in a variety of assets, which leads to a lower level of risk. Meade (1972) concludes that labour co-operatives are less likely to be established, and that those which exist will have a poor financial performance.

Another explanation for the low standard of living in the Russian production co-operatives is that important market forces are distorted, which gives rise to poor performance. Labour cooperatives inherently have an emphasis on the amount and quality of labour that the members provide. Labour is the basis not only for membership, but also for the allocation of profits. However, while the amount and quality of labour is an expression of inputs into the production process, the results of a production process consist of the amount and quality of outputs. This makes it difficult to measure how the amount and quality of labour influence the amount and quality of the final products. This measuring difficulty gives rise to agency problems. If members are remunerated for number of working hours, they have an incentive to work long hours but not to work productively (Ahn et al., 2012). Individuals may also fear that efficiency raising measures might result in fewer working hours even though such measures would raise the economic performance of the collective of members.

Furthermore, the market forces are distorted at the capital market. Equity capital in cooperatives is characterised by high asset specificity. The capital is decided upon by the membership or the manager. As these decisions tend to be based on political rather than economic considerations, it is likely that the amount of equity is lower and the allocation of capital are poorer than if exposed to market forces. According to property rights theory, cooperatives tend to be undercapitalised. Because equity capital is jointly owned members have a disincentive to invest (Furubotn and Pejovich, 1970). "Nonowned assets have lesser appeal 
than fully owned savings deposits for the simple reason that the property rights workers possess in nonowned physical capital are limited to usus fructus.” (Furubotn, 1976, p. 119). Podgorbunskih and Golovina (2005) claim that this holds true in the context of Russian production co-operatives.

The undercapitalisation argument is supported by the observation that the Russian agricultural production co-operatives are orientated towards labour-intense production and have comparatively little investment in fixed assets (Golovina et al., 2013). Instead of using machinery and buildings, they use labour. The logic of labour-intense operations is supported by arguments put forward by Meade (1972): Members of co-operatives are not interested in putting individually owned capital into a collectively owned firm. This reasoning, often labelled a 'capital formation constraint', applies to co-operatives in general. The members want to have the co-operative's profits paid out to them, rather than have the money invested in the co-operative.

The poor financial performance of the Russian production co-operatives may also be due to poor coordination of resources. Many assets within the former Soviet farms were indivisible because Soviet agriculture was highly mechanised and capital-intensive. Thus division of the equipment in an equitable, rational and useful way was difficult and costly (Herrold-Menzies, 2009).

Yet another explanation for the poor performance of the production co-operatives is that they have not only a suboptimal size but also suboptimal composition of different resource types. There is a resistance to increase the degree of heterogeneity within the membership because that might threaten the managers' power base. The consequence is opposition to change, including modernisation measures such as new production technologies and new financial solutions. Hence, Furubotn (1976) concludes that labour co-operatives rank low in allocative efficiency, i.e. resources are not deployed in the most efficient manner.

\section{Conclusions}

The relevance of members' governance costs in the Russian production co-operatives depends on the perspective from which they are assessed. If the members are seen as the principals of co-operatives they must be considered to have high governance costs:

- Costs of collective decision making. If a large group of individuals are to make joint decisions there will be high organisational costs. Hence the decision making for a large group can be delegated to a smaller group according to member democratic principles. The elected representatives are governing the organisation in the best interests of the principals. When the Russian agricultural production co-operatives were established the members were, however, under the control of their former leaders. Member democracy has since not been installed, and hence there is a risk that the decision making is not in accordance with the members' interests.

- Costs of monitoring management. The members' mentality is characterised by collectivism in terms of ownership, governance and operations, and thus subordination to the managers. This means that the members do not care much about monitoring the manager. The members' appreciation of the social networks within the village weighs more highly than their worries about possible poor management of the co-operative.

- Costs of poor decisions and excessive managerial discretion. The members have limited possibilities to find out whether the manager of their co-operative appropriates rents. This information asymmetry means governance costs for the members. The manager is in a position to set a low wage level and decide about the cooperative's business orientation. 
- Costs of risk bearing associated with receipt of residual earnings. The members face governance costs because the annual profits that the co-operatives eventually make are generally not passed on to the members.

If the members' governance costs are seen from the members' own perspective the picture is different. Due to the prevailing mentality of collectivism within the Russian co-operatives the members do not seem to perceive their governance costs to be very high. Both the members' and the managers' view of co-operative management is inherited from the Soviet times. For example, given that the members do not expect to receive the co-operatives' residual earnings, they do not consider themselves to have high governance costs. The members have no experience from democratic elections.

An explanation is that the members' governance costs are related to their transaction costs. The members are more or less locked into the villages because their transaction-specific assets prevent them from getting other employment. For example, their minds and skills are adapted to large agricultural enterprises and life in the rural environment. They have strong social ties to one another. During the years that have passed since the production cooperatives started, the agricultural workers, now co-operative members, still have the same transaction-specific assets.

If co-operatives provide their members with large transaction cost savings, the members will care less about their governance costs. Due to their transaction-specific assets, members are willing to hold out irrespective of the co-operative's performance. Most important is that the co-operatives ensure the workers an acceptable standard of living.

The fact that the members do not care much about their high governance costs means that the managers get lower governance costs. They are then more capable of exerting power with little opposition from the members. This is important to the managers because they have also large asset specificity, linking them to the co-operatives. This also means that they are eager that the co-operative should survive.

An explanation to why the production co-operatives survive in the Russian agriculture is thus that the managers act as if these firms were their private property. For example, the members are treated as if they were employed. The relationship between principals and agents is thus reversed. Even though the firms are formally and legally co-operatives they do not function as such.

The existence of the Russian agricultural production co-operatives is not threatened. The managers have governance costs that are sufficiently low to warrant the co-operatives' survival. It is unlikely that the members will try to acquire individual property rights to the firms, and they are neither capable nor willing to convert these firms from the present autocratic governance structure into genuine co-operatives, i.e. with member control. 


\section{References}

AHN, S.C., BRADA, J.C. and MÉNDEZ, J.A., 2012. Effort, technology and efficiency of agricultural cooperatives. The journal of development studies, 48 (11), 1601-1606.

ALLEN, D. and LUECK, D., 2005. Agricultural contracts. In: C. Ménard and M.Shirley, eds. Handbook of new institutional economics. Dordrecht: Springer, 465-490.

ALLINA-PISANO, J., 2002. The Post-Soviet Potemkin village. Politics and property rights in the Black Earth. Cambridge, UK: Cambridge University Press.

AMELINA, M., 2000. Why Russian peasants remain in collective farms: A household perspective on agricultural restructuring. Post-Soviet geography and economics, 41 (7), 483-511.

ANDERSON, K. and SWINNEN, J., 2010. How distorted have agricultural incentives become in Europe's transition economies? Eastern European economics, 48 (1), 79-109.

BARNEY, J.B. and OUCHI, W.O., 1986. Organizational economics: Toward a new paradigm for understanding and studying organizations. San Francisco, CA: JosseyBass.

BINSWANGER, H., DEININGER, K. and FEDER, G., 1995. Power, distortions, revolt and reform in agricultural land relations. In: J. Behrman, and T.N. Srinivasan, eds. Handbook of development economics. Vol. III. New York, NY: Elsevier, 2659-2772.

BONIN, J.P., JONES, D.C. and PUTTERMAN, L., 1993. Theoretical and empirical studies of producer cooperatives: Will ever the twain meet? Journal of economic literature, 31, 1290-1320.

DEININGER, K., 1993. Cooperatives and breakup of large mechanized farms. Discussion paper 218. Washington DC: World Bank.

DUNN, J.R., 1988. Basic cooperative principles and their relationship to selected practices. Journal of agricultural cooperation, 3, 83-93.

EFENDIEV, A. and SOROKIN, P., 2013. Rural social organization and farmer cooperatives development in Russia and other emerging economies: Comparative analysis. Developing country studies 3 (14), 106-115.

EPSHTEIN, D., HAHLBROCK, K. and WANDEL, J., 2013. Why are agroholdings so pervasive in Russia's Belgorod oblast? Evidence from case studies and farm-level data. Post-communist economies, 25 (1), 59-81.

FURUBOTN, E.G., 1976. The long-run analysis of the labor-managed firm: An alternative interpretation. The American economic review, 66 (1), 104-123.

FURUBOTN, E.G. and PEJOVICH, S., 1970. Property rights and the behavior of the firm in a socialist state: The example of Yugoslavia. Zeitschrift für Nationalökonomie, 30 (3-4), 431-454.

GINDER, R.G. and DELTER, R.E., 1989. Managerial skills, functions and participants. In: D.W. Cobia, ed. Cooperatives in agriculture. Englewood Cliffs, NJ: Prenctice Hall, 308324.

GOLOVINA, S. and NILSSON, J., 2009. Difficulties for the development of agricultural cooperatives in Russia: The case of the Kurgan Region. Journal of rural cooperation, 37 (1), 52-70.

GOLOVINA, S., HESS, S., NILSSON, J. and WOLZ, A., 2014. Social capital in Russian agricultural production co-operatives. Post-communist economies, 26 (4), 522-536.

GOLOVINA, S., NILSSON J. and WOLZ A., 2012. The development of agricultural production cooperatives in the Russian Federation. Journal of rural cooperation, 40 (1), 43-58.

GOLOVINA, S., NILSSON, J. and WOLZ, A., 2013. Members choice of production cooperatives in the Russian agriculture. Post-communist economies, 25 (4), 465-491.

HAGEDORN, K., 2014. Post-socialist farmers' cooperatives in Central and Eastern Europe. Annals of public and cooperative economics 85 (4), 555-577.

HANSMANN, H., 1988. Ownership of the firm. Journal of law, economics, and organization, 4 (2), 281-313. 
HANSMANN, H., 1996. The ownership of enterprise. Cambridge, MA: The Belknap Press.

HARDIN, R. 1982. Collective action. Resources for the future. Baltimore, MD: John Hopkins University Press.

HENDRIKSE, G.W.J. and FENG, L., 2013. Interfirm cooperatives. In: A. Grandori, ed. Handbook of economic Organization. Cheltenham, UK: Edward Elgar, 501-521

HERROLD-MENZIES, M., 2009. The post-collective village: A tale of two transitions. World development, 37 (1), 232-241.

JENSEN, M.C. and MECKLING, W.H., 1976. Theory of the firm: Managerial behavior, agency costs and ownership structure. Journal of financial economics, 3, 305-360.

JOHNSON, N.L. and RUTTAN, V.W., 1994. Why are farms so small? World development, 22 (5), 691-706.

LERMAN, Z. and SCHREINEMACHERS, P., 2005. Individual farming as a labor sink: Evidence from Poland and Russia. Comparative economic studies, 47, 675-695.

LERMAN, Z., CSAKI, C., and FEDER, G., 2004. Agriculture in transition, land politics and evolving farm structures in Post-Soviet countries. Lanham, MD: Lexington books.

MASLOVA, S.I., 2013. Status and prospects of agricultural cooperation. Economic Sciences, Fundamental Research, 6 (part 3), 704-708 (In Russian: Маслова С.И. Состояние и перспективы развития сельскохозяйственной кооперации. Фундаментальные исследования, № 6 (часть 3), 2013). http://www.rae.ru/fs/486-r31578/?lng=en.

MEADE, J.E., 1972. The theory of labour-managed firms and of profit sharing. The economic journal, 82, 402-428.

MICHELS, R., 2001 [1911]. Political parties. A sociological study of the oligarchical tendencies of modern democracy. Kitchener, Ontario: Batoch.

MINAKOV, I.A., 2007. Cooperation and agroindustrial integration in agricultural production cooperatives. Moscow: KolosC (in Russian: Минаков И.А. Кооперация и агропромышленная интеграция в АПК. Москва: КолосС, 2007, 264 с.).

NILSSON, J., 2001. Organisational principles for co-operative firms. Scandinavian journal of management, 17 (3), 329-356.

O’BRIEN, D.J., WEGREN, S.K. and PATSIORKVOSKY, V.V., 2011. Poverty, inequality and subjective quality of life in rural Russia during the transition to a market economy: 1991-2006. Poverty and public policy, 3 (2), 1-26.

OLSON, M., JR., 1965. The logic of collective action. Public goods and the theory of groups. Cambridge, MA: Harvard University Press.

PENCAVEL, J., 2001. Introduction: citizens, consumers, and workers. In: J. Pencavel, ed. Worker participation. Lessons from the worker co-ops of the Pacific Northwest. New York. NY: The Russell Sage Foundation, 1-19.

PETRICK, M. and CARTER, M.R., 2009. Critical masses in the decollectivisation of PostSoviet agriculture. European review of agricultural economics, 36 (2), 231-252.

PETRIKOV, A.V., 2000. Agrarian reform in Russia: Concepts, experience, prospects. Moscow: Izdatel'stvo "Énciklopedija rossijskich dereven". (In Russian: Аграрная реформа в России: Концепции, опыт, перспективы).

PODGORBUNSKIH, P. and GOLOVINA, S., 2005. Theory and practice of agricultural enterprises development: From the classics to institutionalism. Kurgan: Publishing house “Zauralie” (In Russian: Подгорбунских П.Е., Головина С.Г. Теория и практика развития аграрных хозяйств: от классики до институционализма. Под общ. ред. П.Е. Подгорбунских. - Курган: Зауралье, 2005, 440 с.).

POLLAK, R.A., 1985. A transaction cost approach to families and households. Journal of economic literature, 23 (2), 581-608.

PUGACHOV, M. and ATTA, D.V., 2000. Reorganization of agricultural enterprises in Ukraine in 2000: A research note. Post-Soviet geography and economics, 41 (7), 527-540.

ROSSTAT, 2015. Russian Statistical Yearbook: 2014. Statistical Collection. Moscow: Rosstat. (in Russian). 
ROZELLE, S. and SWINNEN, J.F.M., 2004. Success and failure of reform: Insights from the transition of agriculture. Journal of economic literature, 42, 404-456.

SCHILLER, O.M., 1969. Co-operation and integration in agricultural production. London. UK: Asia Publishing House.

SCHMITT, G., 1991. Why is the agriculture of advanced Western economies still organised by family farms? Will this continue to be so in the future? European review of agricultural economics, 18, 443-458.

SHUTKOV, A., 2000. Problems of agricultural output from the crisis. APK: Economics, Management, № 1, 2000, p. 4-17 (In Russian: Шутьков А. Проблемы вывода АПК из кризиса. АПК:экономика,управление. -2000.-№1.-С.4-17).

TIKHOMIROV, V., 2000. The political economy of Post-Soviet Russia. Houndsmill, Hampshire, UK: MacMillan Press.

UZUN, V., 2008. Large and small business in Russian agriculture. In: Z. Lerman, ed. Russia's agriculture in transition. Lanham, MD: Lexington Books, 11-56.

VALENTINOV, V. and CURTISS, J. 2005. Toward a transaction cost theory of organizational change in transitional agriculture. Eastern European economics, 43 (5), 2545.

VALENTINOV, V. and NEDOBOROVSKY, A., 2005. Explaining inertia in organizational change in Ukrainian agriculture. Journal of change management, 5 (4), 485-496.

VALENTINOV, V., 2004. Social capital and organisational performance: a theoretical perspective. Journal for institutional innovation, development and transition, 8, 23-33.

VANEK J., 1970. The general theory of labor-managed market economies. Ithaka, NY: Cornell University Press.

VISSER, O. and SPOOR, M., 2011. Land grabbing in Post-Soviet Eurasia: The world's largest agricultural land reserves at stake. Journal of peasant studies, 38 (2), 299-323.

WANDEL, J., 2011. Business groups and competition in Post-Soviet transition economies: The case of Russian 'agroholdings'. Review of Austrian economics, 24, 403-450.

WEGREN, S.K. and O'BRIEN, D.J., 2002. Introduction: Adaptation and change: Old problems, new approaches. In: D.J. O’Brien and S.K. Wegren, eds. Rural reform in PostSoviet Russia. Baltimore, MD: John Hopkins University Press, 1-20.

WEGREN, S.K., 1998. The conduct and impact of land reform in Russia. In. S.K. Wegren, ed. Land reform in the former Soviet Union and Eastern Europe. London/New York: Routledge, 3-34.

WEGREN, S.K., 2011. Investment trends in Russian agriculture. Russian analyst digest, 99 (12 July), 9-13.

WEGREN, S.K., O'BRIEN, D.J. and PATSIORKOVSKY, V.V., 2008. The economics of rural households in Russia: Impact of village location. Eurasian geography and economics, 49 (2), 200-214. 